\title{
Digital storytelling in the world economy classroom
}

\author{
Valerija Sergeevna Mincicova ${ }^{{ }^{*}}$, Elizaveta Valentinovna Ogloblina ${ }^{1}$, and Asem Hekimoglu \\ Naushabaeva ${ }^{2}$ \\ ${ }^{1}$ Financial University under the Government of the Russian Federation, Department of World \\ Economy and International Business, Moscow, Russia \\ ${ }^{2}$ Bitlis Eren University, Faculty of Economics and Administrative Sciences, Bitlis, Turkey
}

\begin{abstract}
This study aims to share the digital storytelling experience of higher education teachers including those using English as a Medium of Instruction. The methodology consists of giving a task to 130 students of bachelor course divided into 29 creative groups. Students created video stories on prearranged topics concerning the world economy agenda. We focused on analyzing the stages of project creation and the role of a teacher in the process, drivers of successful implementation of the digital storytelling, and compared the effectiveness of different types of classwork with digital storytelling. Thus, we conclude that such factors as the cohesion of the creative groups, ability to use video editing instruments and distribution of the tasks between members in the initial stages play the least important role in the successful implementation of the task, but at the same time can be most easily influenced and course-corrected by a teacher. The research also demonstrated that the potential to connect the topic with the own interests of the creative group, ability to present the result of work publicly and interest in the topic were the main drivers for success and involvement. Those are the characteristics of the generation $Z$, and we strongly believe that the teachers of higher education should consider the findings we present in the results section. It is also revealed that digital storytelling, despite being time-consuming, has a more emotional influence on students and gives them more satisfaction after a presentation.
\end{abstract}

Keywords: higher education, digital education, digital storytelling, world economy studies, teaching gen $Z$, student-centered pedagogy

\section{Introduction}

The modern teacher of higher education is faced with a difficult task. On the one hand, he or she has to develop in students the so-called classical skills that are reflected in the taxonomy of B. Bloom's pedagogical goals: remember, understand, apply, analyze, evaluate, and create [1]. On the other hand, a teacher has to lay the foundations and develop the competencies necessary for a fulfilling life in modern society $[2,3]$.

\footnotetext{
* Corresponding author: valervpavlova@rambler.ru
} 
From the point of view of the evolution of oral communication, digital storytelling can be defined as a natural development of the oral tradition at a new stage [4].

From a technological point of view, digital storytelling is a new modern format for presenting information on the Internet using multimedia technologies [5].

From the sociological point of view, digital storytelling is a means of mediation, which has its social potential, and can even contribute to the strengthening of democracy [6].

Digital storytelling is the application of content methodology [7]. It helps to improve skills of navigating through the galore of information in today's world. It is the instrument of both absorbing and creating knowledge [8]. Formalized storytelling can encourage both reflection, a deeper understanding of a topic and stimulates critical thinking skills [9]. Holders and researchers experience transformative outcomes by crafting and reflecting on digital narratives [10]. It is also a proactive method of education, where one cannot stand aside from group work. And overcoming of isolation and of keeping quiet if you do not understand is one of the main objectives of a modern high school education [11]. Digital storytelling provides meaningful and permanent learning, is fun and motivational [12].

The hypothesis of the research: digital storytelling in education for generation $\mathrm{Z}$ promotes their interest, optimises the understanding of discipline. Its success mostly depends on psychological, social and subjective factors in the study group.

The research aimed to propose a successful mechanism of integration of digital storytelling into educational process to increase the intrinsic motivation of students and develop their higher-order thinking skills.

And thus, we found the objectives for the study:

- $\quad$ Provide proper task, forms of reports, criteria of evaluation;

- Distinguish the factors which make a digital storytelling task inspiring for the students;

- Evaluate the level of knowledge provided in stories, compare it with the knowledge and abilities gained from other forms of work in the classroom.

\section{Methods}

The study was undertaken at the Financial University under the Government of the Russian Federation, Moscow, Russia. The participants of the study are 130 students of the 2 nd and 4th years in bachelor programme in World Economy and International Business studies. The storytelling was executed as a video, created by a group of students, explaining the set problematic situation. The age of the students varied from 19 to 21 years old in 2021, which makes them the paragons of the Generation Z. Students divided themselves into groups of 3-5 people on their own. Finally, 29 video stories were created, presented, analyzed, and discussed in the class.

The videos were created in both Russian (native) and English (foreign) languages. They were presented at the class or accumulated on the specially created website. All the videos were evaluated by the groupmates concerning the stipulated criteria. That evaluation became the basis for a teacher to put the final mark for the task.

\section{$3 \quad$ Results}

First of all, we define the place of digital storytelling in the educational process. It can be implemented within the framework of the study of disciplines according to the curriculum. 
It can also be used for research activities, and the organization of extracurricular work of students.

The use of digital storytelling in the educational process can be implemented in various formats:

- a presentation prepared, for example, using the Microsoft PowerPoint application;

- a filmed video posted on a file hosting service;

- a digital publication with multimedia content.

The 5 stages of work on creating a digital story can be distinguished (see table 1). At each of the designated stages, the teacher organizing the students' work on creating a digital story will have different roles.

Table 1. Teacher's roles in different stages of digital story creating. Developed by the authors on the empirical basis.

\begin{tabular}{|l|c|}
\hline \multicolumn{1}{|c|}{ Stage } & Teacher's Role \\
\hline $\begin{array}{l}\text { Search for an idea and its } \\
\text { development }\end{array}$ & $\begin{array}{l}\text { Manager } \\
\text { Observer } \\
\text { Rapport builder }\end{array}$ \\
\hline Working on the script & $\begin{array}{c}\text { Facilitator } \\
\text { Diagnostician }\end{array}$ \\
\hline Storyboarding and editing & Observer \\
\hline Publication of results & Manager \\
\hline Presentation & Assessor \\
\hline
\end{tabular}

At the stage of searching for an idea, it is necessary to direct students as accurately as possible to formulate the topic of a digital story. At the initial stage, the abundance of information and topics can significantly complicate the work of students and lead them away from the goals and objectives set by the teacher. In this regard, it is recommended to provide extensive advisory assistance to students at the initial stage.

Further, students determine the purpose of the study and prepare a justification for the relevance of the research topic. Students collect information on the topic and carry out its primary analysis in the form of an annotated bibliographic list of reliable sources.

The work on the script also supposes the active involvement of a teacher in the process of its preparation, since students need help in finalizing it. The format for presenting the digital story are the following, each of them is accompanied with the list of programs and applications mostly used:

- Doodle video: VideoScribe, Powtoon, Sparkol;

- Animated storytelling: Powtoon, GoAnimate, Toon Boom;

- Comics \& Storyboards: Pixton, StoryboardThat, Canva;

- Presentations: PowerPoint, Prezi, Sway;

- Video Editing: iMovie, YouTube Editor, Windows Live.

As for the actual programmes on PC students prefer Microsoft Windows Live Movie Maker, Microsoft PowerPoint, iMovie as has been noted for other European students [13]. Smart phone and tablet applications differ significantly.

The stage of storyboarding and video editing begins with a one-second storyboard and script adjustments. It can be presented in the form of a table, including the following mandatory columns:

- Sequential frame number;

- Frame time in seconds;

- Text on screen;

- Video;

- Sound. 
Presenting digital stories involves evaluating them. The criteria for evaluating a digital story can be proposed as follows:

- Content of digital story (depth of topic disclosure and relevance of the content to the declared topic);

- $\quad$ Digital story structure (consistency of presentation);

- Use of technologies (video and sound).

As for the topics, the most interesting of them appeared to be those concerning the history of organizations, processes, stories of success (such as "BP ecology management" or "Flying geese paradigm in Asian Tigers rise"), and concerning the political cases influencing economics (such as new trends in pandemic-ruled world: "India's economy hit by COVID-19", "European tourist sector collapse" [14]). This trend is stipulated by the determinants of the Generation Z, highlighted as preferences for group-work, affirmation, clear rules, and for their opinions to be valued [15].

We evaluated how different characteristics of the study group drew interest to the task implementation (Table 2).

Table 2. Drivers of successful implementation of the digital storytelling task in a student's class.

Developed by the authors on the empirical basis.

\begin{tabular}{|l|c|l|}
\hline \multicolumn{1}{|c|}{$\begin{array}{c}\text { Which factor drew interest to } \\
\text { the task? }\end{array}$} & $\begin{array}{c}\text { Meaning of the } \\
\text { factor for successful } \\
\text { implementation of } \\
\text { the task } \\
(\mathbf{1 - 1 0} \text { points })\end{array}$ & $\begin{array}{l}\text { Can the factor be influenced } \\
\text { by the tutor? }\end{array}$ \\
\hline Cohesion of the creative group & 3 & $\begin{array}{l}\text { Can be influenced while the } \\
\text { teaching process }\end{array}$ \\
\hline Strong leadership inside the group & 5 & Should not be influenced \\
\hline Ability of video editing & 4 & $\begin{array}{l}\text { Can be influenced while } \\
\text { posing a task }\end{array}$ \\
\hline Interest in the topic & 8 & $\begin{array}{l}\text { Can be influenced while } \\
\text { posing a task }\end{array}$ \\
\hline $\begin{array}{l}\text { Ability of public presentation of } \\
\text { the video }\end{array}$ & 7 & $\begin{array}{l}\text { Can be influenced while } \\
\text { posing a task }\end{array}$ \\
\hline $\begin{array}{l}\text { Potential to connect the topic with } \\
\text { the own interests of the creative } \\
\text { group }\end{array}$ & 10 & $\begin{array}{l}\text { Accidental, can be influenced } \\
\text { if the topic is changed }\end{array}$ \\
\hline $\begin{array}{l}\text { Ability to distribute the tasks } \\
\text { while preparation }\end{array}$ & 4 & $\begin{array}{l}\text { Can be influenced } \\
\text { prescriptively }\end{array}$ \\
\hline $\begin{array}{l}\text { The topic connected with the } \\
\text { interests of Gen } Z\end{array}$ & 10 & $\begin{array}{l}\text { Accidental, but can be } \\
\text { corrected at initial stage }\end{array}$ \\
\hline
\end{tabular}

Student feedback confirms our conclusions on drivers of interest, the role of a student and a teacher, the mechanism of forming a group, etc. And it also confirms the actual hypothesis of the study.

Digital storytelling has its difficulties. It is quite labour intensive and time demanding (no less than 4 hours of work of the group per a video of 3 minutes) task type. But if we compare it with other types of work it wins in many criteria as shown in table 3.

Table 3. Comparison of effectiveness of different classical types of classwork with digital storytelling.

Developed by the authors on the empirical basis. 


\begin{tabular}{|l|c|c|c|c|c|}
\hline & $\begin{array}{c}\text { Digital } \\
\text { storytellin } \\
\text { g }\end{array}$ & $\begin{array}{c}\text { Q\&A } \\
\text { (answers } \\
\text { prepared) }\end{array}$ & $\begin{array}{c}\text { Discussion } \\
\text { with } \\
\text { scenario }\end{array}$ & $\begin{array}{c}\text { Unprepared } \\
\text { discussion }\end{array}$ & $\begin{array}{c}\text { Text analysis } \\
\text { with control } \\
\text { questions }\end{array}$ \\
\hline $\begin{array}{l}\text { Digestion of the } \\
\text { discipline } \\
\text { material }\end{array}$ & $\mathrm{H}$ (high) & $\mathrm{H}$ & $\mathrm{H}$ & $\mathrm{M}$ (medium) & $\mathrm{M}$ \\
\hline Memorisation & $\mathrm{M}$ & $\mathrm{H}$ & $\mathrm{M}$ & $\mathrm{L}(\mathrm{low})$ & $\mathrm{M}$ \\
\hline Interpretation & $\mathrm{H}$ & $\mathrm{L}$ & $\mathrm{M}$ & $\mathrm{H}$ & $\mathrm{L}$ \\
\hline Application & $\mathrm{M}$ & $\mathrm{L}$ & $\mathrm{H}$ & $\mathrm{H}$ & $\mathrm{M}$ \\
\hline
\end{tabular}

Digital storytelling has a more emotional influence on students and gives them more satisfaction after presentation, although it lacks the effectiveness in memorization of all the material given for the rest of the group except the video authors.

Being a modern type of task, the digital storytelling has its certain demands for equipment. That establishes the demands for the university campus that should provide such equipment and software for everyone to be able to execute the task.

We also registered that the students experienced difficulties in scriptwriting, mostly while making short clear sentences, in finding the related images, videos and photographs. Despite the fact that they have a rich experience in such type of work, those difficulties are still present. But finally, the students concluded, that practically all topics are suitable for digital storytelling, even the ones demanding a sound scientific research.

\section{Discussion}

Our experience and study show that creating digital stories can be executed both with the strong participance of a teacher and without it. And if the group is motley enough it risks failing making a good product. So, we insist on the active position of a teacher at least at first stages. This viewpoint can be challenged, as generation $Z$, which we speak of in this study, appreciates their freedom and diversity. But modern higher school society is not ready for the education process without a supervisor, advisor, manager, facilitator, source of experience and knowledge, and mentor - a higher education teacher.

\section{Conclusion}

All new forms that provide effective communication and information presentation, which include digital storytelling, are in demand in various spheres of private, business and public life, including the academic environment. The digital storytelling format is a good example of how students rethink actual world economy topics competently and engagingly. This method of information presenting is a successful combination of traditional communication techniques and modern computer visualization capabilities. Modern programmes and services offer convenient development tools and resources that facilitate the creation of digital stories.

It should be noted that digital storytelling technology justifies the time spent, as it allows to consolidate and apply in practice a whole range of competencies related to the use 
of text, graphics, photos, audio, video, develops speech skills and stimulates internal motivation for learning.

\section{References}

1. Bloom's Taxonomy Is a Hierarchical Framework for Cognition and Learning Objectives. Accessed on: September 25, 2021. [Online]. Available:

https://www.teachthought.com/learning/what-is-blooms-taxonomy-a-definition-for-tea chers/

2. J. Soffel, Ten 21 st-century skills every student needs (2016). Accessed on: September 25, 2021. [Online]. Available:

https://www.weforum.org/agenda/2016/03/21st-century-skills-future-jobs-students/

3. Iniciativa "Navyki budushchego" [The "Skills of the Future" initiative] Accessed on: September 25, 2021. [Online]. Available:

https://asi.ru/leaders/initiatives/education_leaders/future_skills/

4. Digital Storytelling for Communities. Accessed on: September 25, 2021. [Online]. Available: https://librarydigitalstorytelling.wordpress.com/why/

5. A.A. Kolosova, N.V. Poplavskaya, Cifrovye tekhnologii v sozdanii novyh formatov $m$ ediatekstov [Digital technologies in the creation of new media text formats], in Medialingvistika. Vypusk 5: yazyk v koordinatah massmedia: sbornik materialov I Mezhdunarodnoj nauchno-prakticheskoj konferencii, 39, 6-9 September, 2016 (Varna, 2016)

6. N. Couldry, New Media Soc, 10(3), 373-391. (2008).

https://doi.org/10.1177/1461444808089414

7. K. Daniels, J Sch Edu Tech, 9(1), 1-10 (2013)

8. L.M. Dreyer, South Afr J Edu, 37(4), 1-10 (2017) https://doi.org/10.15700/saje.v37n4a1475

9. M. Alterio, J. McDrury, Learning Through Storytelling in Higher Education: Using Reflection and Experience to Improve Learning (Routledge, 2003). https://doi.org/10.4324/9780203416655

10. C. Lenette, Digital Storytelling, in Arts-Based Methods in Refugee Research (Springer, Singapore, 2019). https://doi.org/10.1007/978-981-13-8008-2_5

11. H.L. Schnackenberg, C. Johnson, Preparing the Higher Education Space for Gen $Z$ (IGI Global, Hershey, 2019). https://doi.org/10.4018/978-1-5225-7763-8

12. G. Gürsoy, Europ J Edu Res, 10(1), 97-113 (2021).

https://doi.org/10.12973/eu-jer.10.1.97

13. G. Gürsoy, Digital Storytelling, in New Trends in Educational Sciences (SRA Academic Publishing, 2020)

14. K. Liuhto, The world economy in 2020 (2020). https://doi.org/:10.13140/RG.2.2.30689.94566

15. H. Raslie, Stud App Econ, 39(1) (2021). https://doi.org/10.25115/eea.v39i1.4268 